\title{
Myocardial Response in Preterm Fetal Sheep Exposed to Systemic Endotoxinaemia
}

\author{
MATTHIAS SEEHASE, MARKUS GANTERT, ANDREAS LADENBURGER, YVES GARNIER, STEFFEN KUNZMANN, \\ WOLFGANG THOMAS, JOHANNES WIRBELAUER, CHRISTIAN P. SPEER, AND BORIS W. KRAMER
}

\begin{abstract}
Department of Paediatrics [M.S., B.W.K.], Maastricht University Medical Center, Maastricht NL-6202, the Netherlands; Department of Obstetrics and Gynaecology [M.G., Y.G.], Hospital Osnabrück, Osnabrück D-49076, Germany; Department of Neonatology [M.S., A.L., S.K., W.T., J.W., C.P.S.], University Children's Hospital, Würzburg D-97080, Germany
\end{abstract}

\begin{abstract}
Exposure of the fetus to antenatal inflammation can occur from chorioamnionitis, which may progress to a fetal inflammatory response syndrome (FIRS) and to fetal sepsis. We tested whether the fetal myocardium responded to systemic Gram-negative endotoxinaemia. We hypothesized that the myocardium would respond to inflammation by changes in hypoxia-inducible factor- $\alpha$ (HIF-1 $\alpha$ ), inducible NO-synthase (iNOS), Toll-like receptors 2 and 4 (TLR2 and TLR4), IL-6, and phosphorylated signal transducer and activator of transcription-3 (pSTAT3). To model systemic endotoxinaemia, fetal sheep were exposed to Gram-negative endotoxin or saline i.v. $3 \mathrm{~d}$ before preterm delivery at $113 \mathrm{~d}$ of gestation (term $=$ $147 \mathrm{~d})$. All endotoxin-exposed animals developed cardiac dysfunction within these $72 \mathrm{~h}$. Cardiac mRNA and protein levels of HIF-1 $\alpha$ and TLR2 and TLR4 mRNA increased, whereas STAT3 phosphorylation decreased significantly. IL-6 and iNOS mRNA remained unchanged. Fetal systemic endotoxinaemia induced myocardial inflammation by activating TLR2 and 4 . The following cardiac dysfunction seems not to be mediated via cardiac iNOS. (Pediatr Res 70: 242-246, 2011)
\end{abstract}

$\mathrm{C}$ ardiovascular dysfunction is a severe consequence of the systemic inflammatory response syndrome (SIRS) (1). A number of experiments in vivo and in vitro have been performed to study the mechanism of endotoxin-induced cardiac dysfunction in the adult (2). According to previous studies, it is mediated by proinflammatory cytokines as IL- $6(3,4)$ leading to excessive NO production, generated as a result of the induction of inducible NOS (iNOS) (5). These processes are controlled by signal transducer and activator of transcription-3 (STAT-3), which is activated on phosphorylation $(6,7)$.

Until now, this sequence has not been studied in the fetus. The proposed fetal counterpart to SIRS, the fetal inflammatory response syndrome (FIRS) results from an infection of the amniotic cavity called chorioamnionitis (8). FIRS is the precursor of neonatal early-onset sepsis and has been associated with fetal death, preterm premature rupture of membranes (PROM), and consequently spontaneous preterm labor, and cardiorespiratory failure, or hypoxic-ischemic brain damage at birth $(9,10)$.

Received November 29, 2010; accepted March 15, 2011.

Correspondence: Boris W. Kramer, M.D., Ph.D., Department of Pediatrics, Maastricht University Medical Center, P. Debyelaan 25, 6229 HX Maastricht, Postbus 5800, 6202 AZ Maastricht, the Netherlands; e-mail: b.kramer@mumc.nl

Supported by the Deutsche Forschungsgemeinschaft (KU 1403/2-1) and Interdisciplinary Center for Clinical Research, University Wuerzburg, Germany IZKF Z-08 and NIH HL-65397; and VENI grant 0.16.096.141 [B.W.K.]
Early onset neonatal sepsis remains an important cause of illness and death among very LBW preterm infants. More than one half of early infections caused by Gram-negative organisms (53\%), with Escherichia coli the most common organism (41\%) (11). Endotoxins from Gram-negative bacteria (lipopolysaccharide) bind to Toll-like receptors 2 and 4 (TLR2 and TLR4), which leads to the activation of nuclear factor (NF)- $\kappa \mathrm{B}$, required for transcriptional activation of proinflammatory cytokines and several other inflammatory mediators (12). FIRS may launch a cytokine cascade similar to SIRS (8). Until now, it is not known whether the different fetal microenvironment with a relative lack of oxygen (13) and the more tolerant fetal immune system (14) allows the fetal heart to respond to systemic endotoxinaemia in the same way as the adult heart does. Therefore, we developed a preterm sheep model to study the physiologic responses, inflammatory signal transmission, and concomitant hemodynamic alterations in the fetus. We hypothesized that i.v. endotoxin causes a cardiac fetal inflammatory response by activating TLR2 and TLR4 and inducing a cytokine cascade and NO production that lead to arterial hypotension, tachycardia, and cardiac hypoxia.

\section{METHODS}

Animals. The study was performed at Maastricht University, the Netherlands, with the approval of the local Animal Medical Ethics Committee [Dier experimentelle commissie (DEC), Universiteit Maastricht, 2006, file number DEC 2006-125]. Eleven fetal sheep were chronically instrumented at a GA of $107 \mathrm{~d}$ (term is $147 \mathrm{~d}$ ) as described previously (15). Briefly, all ewes received general anesthesia (thiopental sodium $1 \mathrm{~g} / 70 \mathrm{~kg}$ i.v. for induction, 0.5 to $1.0 \%$ halothane in a 1:1 nitrous oxide, and oxygen for maintenance). Through a midline abdominal incision, the fetal limbs were exteriorized through an incision in the uterus. Polyvinyl catheters (Maxxim Medical BV, Den Bosch, the Netherlands) with $0.75 \mathrm{~mm}$ inner diameter and $1.25 \mathrm{~mm}$ outer diameter were inserted via a fetal tibial vein and artery of each hindleg and advanced into the caudal vena cava and abdominal aorta, respectively. The fetal skin was closed with cyanoacrylate glue (Cyanolit, Japan). Catheters were filled with heparin (100 IU/mL; Heparin-Natrium; Braun, Melsungen, Germany) and passed through a small incision in the flank of the ewe. The ewes received

Abbreviations: $\boldsymbol{C}_{\mathbf{t}}$, cycle threshold; FHR, fetal heart rate; FIRS, fetal inflammatory response syndrome; HIF-1 $\alpha$, hypoxia-inducible factor- $\alpha$; iNOS, inducible NOS; MABP, mean arterial blood pressure; ovRPS15, ovine ribosomal protein S15; pSTAT3, phosphorylated signal transducer and activator of transcription-3; SIRS, systemic inflammatory response syndrome; STAT3, signal transducer and activator of transcription-3; TBS, Tris-buffered saline; TLR2, Toll-like receptor-2; TLR4, Toll-like receptor-4 
$1 \mathrm{~g}$ ampicillin (Pentrexyl; Bristol-Myers, Woerden, the Netherlands) s.c. and 10 $\mu \mathrm{g}$ buprenorphin (Temgesic; Schering, the Netherlands) per kg body weight twice a day for 3 consecutive postoperative days. A recovery period of $3 \mathrm{~d}$ followed the operation before the experiments were started. Fetuses of the control group $(n=6)$ received saline infusion $(5 \mathrm{~mL}$ saline $0.9 \%)$, whereas fetuses of the study group $(n=5)$ received $100 \mathrm{ng}$ endotoxin i.v. (16) (lipopolysaccharide, $E$. coli, batch 055:B5; Sigma Chemical Co.-Aldrich, Frankfurt, Germany; in $5 \mathrm{~mL}$ saline $0.9 \%$ ). Solutions were infused over $10 \mathrm{~min}$. Fetal heart rate (FHR) and mean arterial blood pressure (MABP) were continuously recorded during the experiment on a personal computer, using a customized hemodynamic data acquisition system (University of Maastricht, the Netherlands). Blood samples were taken at various time points (i.e. $-1,1,3,6,12,24,48$, and $72 \mathrm{~h}$ ) from the fetal descending aorta and analyzed for blood gases, acid base balance (AVL 993; Radiometer, Copenhagen, Denmark), Hb concentration, and arterial oxygen saturation of $\mathrm{Hb}$ (OSM2 Hemoximeter; Radiometer). After the experiment, the $113 \mathrm{~d}$ old fetuses were given an overdose of sodium pentobarbitone $(150 \mathrm{mg} / \mathrm{kg})$. A circular piece of cardiac tissue was excised from beneath the left coronary artery and snap-frozen for RNA and protein analysis.

RNA extraction. Eighty cryostat sections from the frozen left ventricular myocardial tissue were made. The sections were transferred into RLT-Buffer (Qiagen, Hilden, Germany) for RNA extraction. After vortexing, the suspension was transferred to an RNeasy mini column (Qiagen, Hilden, Germany) and processed according to the manufacturer's protocol.

Reverse transcription. Purity and yield of the RNA were photometrically determined, and $1 \mu \mathrm{g}$ total RNA was reverse transcribed by addition of $2 \mu \mathrm{L}$ oligo (dT) primers $(10 \mu \mathrm{M}), 1 \mu \mathrm{L}$ RNase inhibitor (10 units/ $\mu \mathrm{L}), 2 \mu \mathrm{L}$ dNTP Mix ( $5 \mathrm{mM}$ ), and Omniscript transcriptase ( $0.2 \mathrm{U} / \mu \mathrm{L}$; Qiagen, Hilden, Germany) for $1 \mathrm{~h}$ at $37^{\circ} \mathrm{C}$. The cDNA was denaturated at $93^{\circ} \mathrm{C}$ for $5 \mathrm{~min}$.

Real-time PCR. The design of PCR primers was based on published nucleotide sequences of the ovine IL-6, TLR2, TLR4, iNOS, hypoxiainducible factor- $\alpha$ (HIF-1 $\alpha$ ), and the house-keeping gene ovine ribosomal protein S15 (ovRPS15, Table 1). The TLR4-, iNOS-, HIF-1 $\alpha$-, and ovRPS15 quantitative real-time PCR (TaqMan) primers and probes were purchased from Applied Biosystems (Weiterstadt, Germany), the TLR2- and IL-6 primers and probe were obtained from Sigma Chemical Co.-Aldrich Chemie $\mathrm{GmbH}$ (Munich, Germany). All PCRs except for IL-6 were performed using $1 \mu \mathrm{g} / \mu \mathrm{L}$ cDNA per reaction in duplicates in $30 \mu \mathrm{L}$ on an ABI Prism 7300 Sequence Detection System (TaqMan) using a 2-step PCR protocol after

Table 1. Target primer and probe sequences with optimized concentrations

\begin{tabular}{|c|c|}
\hline \multicolumn{2}{|l|}{ TLR4 } \\
\hline FwdP $(10 \mathrm{nM})$ : & 5'-GAGAAGACTCAGAAAAGCCTTGCT-3' \\
\hline $\operatorname{RevP}(10 \mathrm{nM})$ : & 5'-GCGGGTTGGTTTCTGCAT-3' \\
\hline Probe $(6 \mathrm{nM})$ : & $\begin{array}{l}\text { 5'-6FAM-TAAACCCCAGAGTCCAGAAGGAA } \\
\text { CAGCA-TAMRA-3' }\end{array}$ \\
\hline \multicolumn{2}{|l|}{ TLR2 } \\
\hline FwdP $(10 \mathrm{nM})$ : & 5'-CTGGGATCTTAGAAGTAGAGTTTG-3' \\
\hline $\operatorname{RevP}(10 \mathrm{nM})$ : & 5'-CTAATTCTGTTCAAAGTCAGTGC-3' \\
\hline Probe & 5'-6FAM-AATCGCCAACTCCATCA-TAMRA-3' \\
\hline \multicolumn{2}{|r|}{ ( } \\
\hline FwdP $(10 \mathrm{nM})$ : & 5'-TGATGCAGAAGGCCATGTCA-3' \\
\hline $\operatorname{RevP}(10 \mathrm{nM})$ : & 5'-TCTCCCTGTCTCTGTTGCAAAG-3' \\
\hline Probe $(6 \mathrm{nM})$ : & $\begin{array}{l}\text { 5'-6FAM-CCCGGGTCAGAGCCACGAT } \\
\text { CC-TAMRA-3' }\end{array}$ \\
\hline \multicolumn{2}{|r|}{ 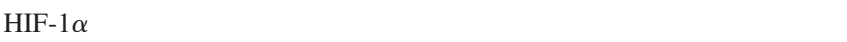 } \\
\hline FwdP $(10 \mathrm{nM})$ : & 5'-CGC ATC TTG ATA AGG CTT CTG TT-3' \\
\hline $\operatorname{RevP}(10 \mathrm{nM})$ : & 5'-CAC CAG CAT CCA GAA GTT TCC T-3' \\
\hline Probe $(6 \mathrm{nM})$ : & $\begin{array}{l}\text { 5'-6FAM-TGA GGC TCA CCA TCA GCT ATT TGC } \\
\text { GTG-MGBNFQ-3' }\end{array}$ \\
\hline \multicolumn{2}{|r|}{ 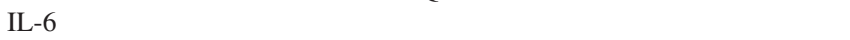 } \\
\hline FwdP $(10 \mathrm{nM})$ : & 5'-ACATCGTCGACAAAATCTCTGCAA-3' \\
\hline $\operatorname{RevP}(10 \mathrm{nM})$ : & $\begin{array}{l}\text { 5'-GCCAGTGTCTCCTTGCTGTTT-3' } \\
\text { SYBR Green }\end{array}$ \\
\hline \multicolumn{2}{|l|}{ ovRPS15 } \\
\hline FwdP $(10 \mathrm{nM})$ : & 5 '-CGAGATGGTGGGCAGCAT-3' \\
\hline $\operatorname{RevP}(10 \mathrm{nM})$ : & 5 '-GCTTGATTTCCACCTGGTTGA-3' \\
\hline Probe $(6 \mathrm{nM})$ : & $\begin{array}{l}5 \text { '-VIC-CCGGCGTCTACAACGGCAAGA } \\
\text { CC-TAMRA-3' }\end{array}$ \\
\hline
\end{tabular}

Fwd P, forward primer; Rev P, reverse primer; 6FAM, fluorescent reporter dye; TAMRA, fluorescent quencher dye; VIC, fluorescent reporter dye; MGBNFQ, nonfluorescent quencher dye (Applera Corporation). initial denaturation of the DNA $\left(10\right.$ min at $\left.95^{\circ} \mathrm{C}\right)$ with 40 cycles of $95^{\circ} \mathrm{C}$ for $15 \mathrm{~s}$ and $60^{\circ} \mathrm{C}$ for $1 \mathrm{~min}$. Universal master mix from Applied Biosystems included all reagents including Taq-polymerase apart from specific primers and probes. IL-6 PCR was performed with $1 \mu \mathrm{g} / \mu \mathrm{L}$ cDNA per reaction in duplicates of $25 \mu \mathrm{L}$ with an iCycler 5 (BioRad, Veenendaal, the Netherlands) using SYBR Green instead of a probe and the same 2-step PCR protocol as described above. Universal master mix "ABsolute blue QPCR SYBR Green fluorescein" was from Westburg (abGene, United Kingdom) including all reagents and Taq polymerase apart from specific primers. Dilution experiments were performed to ensure similar efficiency of the PCRs, and standard curves were calculated for the threshold cycle $\left(C_{\mathrm{t}}\right)$ to the log of each cDNA dilution step. All amplification batches included no template controls and cDNA aliquots from hearts, which were not exposed to endotoxin. Neither negative controls nor cardiac mRNA from control hearts led to elevated fluorescence signals after PCR. Dilution experiments of cDNA aliquots resulted in a very similar amplification efficiency of the different targets with gradients ranging from -3.45 to $-3.65\left(R^{2}\right.$, $0.9766-0.9961$ ). Thus, results of IL-6, TLR2, TLR4, iNOS, and HIF-1 $\alpha$ were normalized to ovRPS15 and mean fold changes in mRNA expression were calculated by the $\Delta \Delta C_{\mathrm{t}}$ method (17).

Western blotting. Frozen heart tissue was homogenized in ice-cold RIPA buffer (R0278-50ML; Sigma Chemical Co.-Aldrich Corp., St. Louis, MO) containing Halt Protease and Phosphatase Inhibitor Cocktail, EDTA-free $(100 \times)(78445$; Thermo Fisher Scientific, Inc., Rockford, IL). The samples were then centrifuged at $500 \times g$ for $20 \mathrm{~min}$ at $4^{\circ} \mathrm{C}$ to remove cellular debris. Protein content in the supernatant was determined using the Micro BCA Protein Assay Kit (23235; Thermo Fisher Scientific, Inc.), with BSA as the standard. Proteins were denatured by heating at $95^{\circ} \mathrm{C}$ for $10 \mathrm{~min}$ in an electrophoresis buffer containing 4\% (wt/vol) SDS, Tris- $\mathrm{HCl} 40 \mathrm{mM}, \mathrm{pH} 6.8$, glycerol 47\% (vol/vol), EGTA $16 \mathrm{mM}$, bromophenol blue $0.05 \%$ (wt/vol), and 1,4-DTT $16 \mathrm{mM}$ using $30 \mu \mathrm{g}$ of protein. Separation of proteins was performed in SDS-PAGE [7.5\% (wt/vol) acrylamide]. After electrophoretic separation in a Protean 3 Electrophoresis System (Bio-Rad, Munich, Germany), proteins were transferred to a Protran BA83 nitrocellulose membranes (Whatman GmbH, Dassel, Germany) by semidry electrophoretic blotting with the use of a Mini Trans-Blot Electrophoretic Transfer Cell (Bio-Rad) using $350 \mathrm{~mA}$ and $100 \mathrm{~V}$ for $60 \mathrm{~min}$ at $4^{\circ} \mathrm{C}$. To block unspecific binding, the sheets were immersed in a 1:1 mixture of TBS (Tris/HCl: $2.5 \mathrm{mM}, \mathrm{NaCl}: 170 \mathrm{mM}$, $\mathrm{pH}$ 7.5) and ODYSSEY Infrared Imaging System Blocking Buffer (92740000; LI-COR, Lincoln, NE). After repeated washes with TBS/Tween20 [Tris/HCl: $2.5 \mathrm{mM}, \mathrm{NaCl}: 170 \mathrm{mM}$, Tween20: $1 \%$ (vol/vol), $\mathrm{pH} 7.5$ ], the sheets were incubated with the first antibody. All primary antibodies were added to a mixture of 1:1 TBS-buffer and ODYSSEY Infrared Imaging System Blocking Buffer. The following dilutions were used: 1:1000 for monoclonal anti- $\beta$-actin clone AC-1 (Sigma Chemical Co-Aldrich Catalog Number A5441) and 1:1000 for rabbit anti-pSTAT3-Tyr.705 (9131; Cell Signaling Technology, Inc., Danvers, MA).

The antibodies were diluted and incubated over night at $4^{\circ} \mathrm{C}$. As secondary antibody IRDye680 conjugated goat (polyclonal) anti-rabbit IgG, and IRDye680 conjugated goat (polyclonal) anti-mouse IgG were used in a dilution of 1:5000. The antibodies were diluted and incubated for $1 \mathrm{~h}$ at room temperature. After further washes, the blots were analyzed using the LICOR Odyssey Infrared Imaging System, and images were acquired using Adobe Photoshop CS4 software. All other chemicals were of analytical grade or the best grade commercially available. Only deionized and double-distilled water was used.

Immunohistochemistry. The immunostaining methods were performed as previously described (18). Myocardial tissue was cut in $5 \mu \mathrm{m}$ frozen sections. Endogenous peroxidase activity was removed by incubation with hydrogen peroxide. Nonspecific binding sites were blocked with goat serum. Sections were incubated at $4^{\circ} \mathrm{C}$ overnight with a rabbit MAb for HIF- $1 \alpha$ that cross reacts with sheep (Novum Biologicals, NJ). After being washed with TBS to remove unbound antibody, the slides were incubated with the secondary biotinylated antibody against rabbit (Vector Laboratories, CA) for $1 \mathrm{~h}$ at room temperature. Immunostaining was visualized by the Vectastain $\mathrm{ABC}$ peroxidase Elite kit to detect the antigen-antibody complexes (Vector Laboratories). Staining was scored from $0^{\circ}$ (no expression) to $4^{\circ}$ (highest expression) by two analysts unaware of the assignment of the animals.

Data analysis. Data were given as mean \pm SEM. Physiologic variables such as oxygen saturation were analyzed using 2-way ANOVA. All other data were analyzed by the Mann-Whitney-Wilcoxon test. A $p$ value $<0.05$ was considered significant. All statistical analyses were performed using the statistical software GraphPad Prism 5.0.

\section{RESULTS}

Physiologic variables and blood gases. FHR, MABP, and oxygen saturation were stable and in normal range in all control 

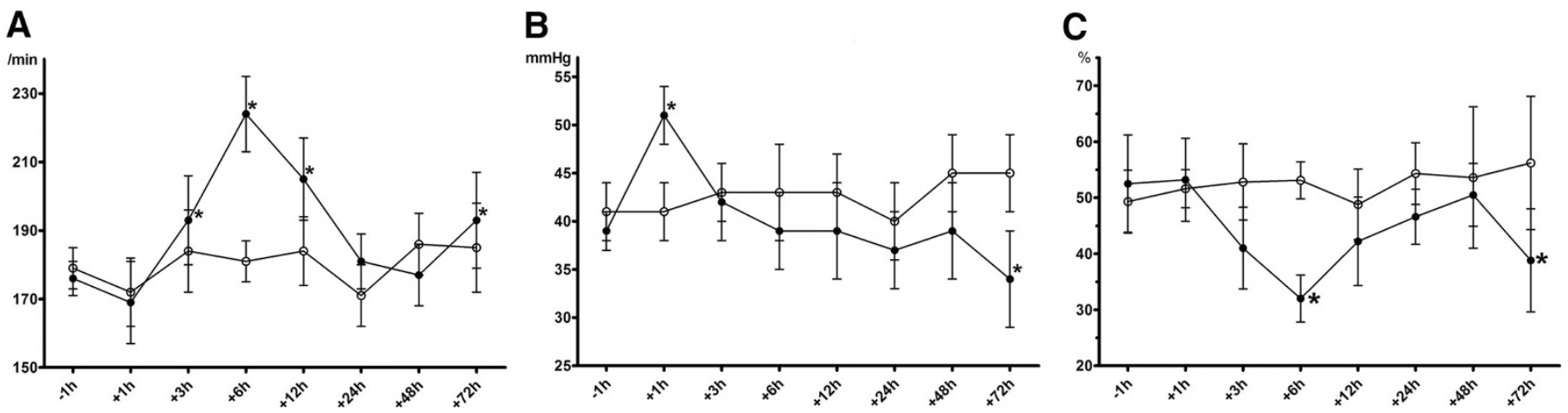

Figure 1. Physiological changes in fetal heart frequency $(A)$, MABP $(B)$, and arterial oxygen saturation $(C)$. Depicted are mean \pm SEM. Solid black circles represent the i.v. endotoxin group $(n=5)$, empty circles, the controls $(n=6)$. Significant differences $(p<0.05) v s$ corresponding control group are marked by *.
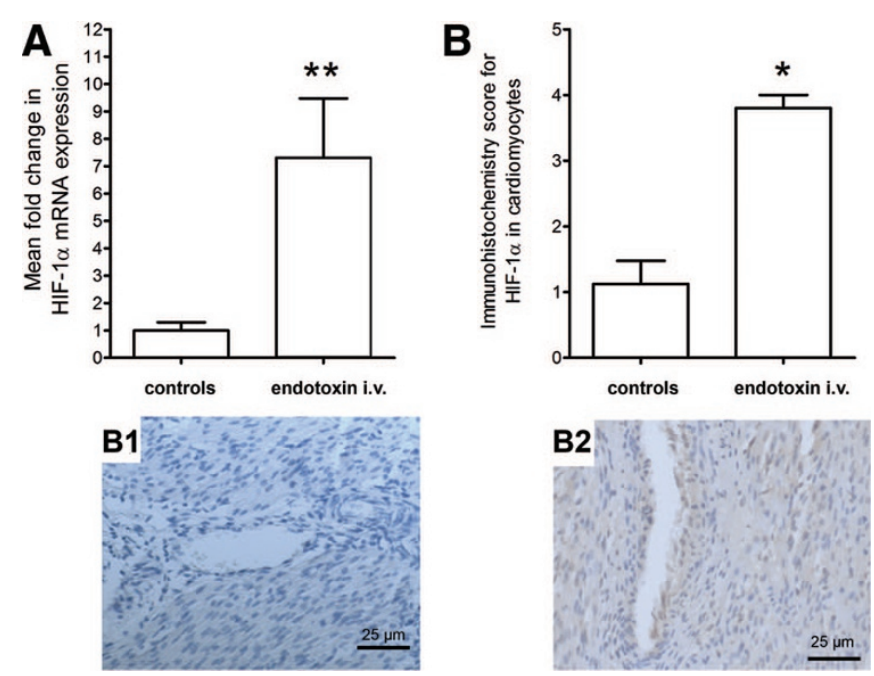

Figure 2. (A) Mean fold change \pm SEM of cardiac HIF- $1 \alpha$ mRNA normalized for ovRPS15 by the $\Delta \Delta C_{\mathrm{t}}$ method. Significant differences in $\Delta C_{\mathrm{t}}(p<$ $0.05)$ compared with control groups are marked by $*$. The difference in mRNA between control $(n=6)$ and endotoxin i.v. group $(n=5)$ was significant. (B) Immunohistochemistry for HIF-1 $\alpha$ in fetal myocardium. Magnification of scale bar is $25 \mu \mathrm{m}$. Tissue from control animals $(n=6)$ showed little expression of HIF- $1 \alpha(B 1)$. Three days after i.v. administration $(n=5)$ of endotoxin, a significant increase was observed (B2). Staining was scored from 0 (no expression) to 4 (highest expression) by two analysts unaware of the assignment of the animals. The difference in expression between endotoxin i.v. and controls was significant. Significant differences $(p<0.05)$ are marked by $*(B)$.

animals during the whole experiment. In the endotoxinaemia group, FHR increased $6 \mathrm{~h}$ after exposure to endotoxin to $124 \%$ compared with values of control animals (Fig. 1A). After normalization into normal range in the meantime, FHR starts to rise again when MABP and oxygen saturation starts to decompensate and was in the end of the experiment at $104 \%$ compared with control animals. MABP rose by $23.5 \% 1 \mathrm{~h}$ after endotoxin administration and then decreased to $75.6 \%(p<0.05)$ compared with control animals (Fig. 1B). Oxygen saturation was $40 \%$ lower in the endotoxinaemia group at $6 \mathrm{~h}(p<0.05)$ and recovered slowly during the following $24 \mathrm{~h}$ but starting to decrease again after $48 \mathrm{~h}$ and remained $31 \%$ lower after $72 \mathrm{~h}$ $(p<0.05)$ compared with control animals (Fig. 1C).

Hypoxia-inducible factor-1 $\alpha$. The mRNA level for HIF- $1 \alpha$ increased 7.3-fold in the fetal endotoxinaemia group compared with controls $(p<0.01$; Fig. $2 A)$. Immunohistochem-
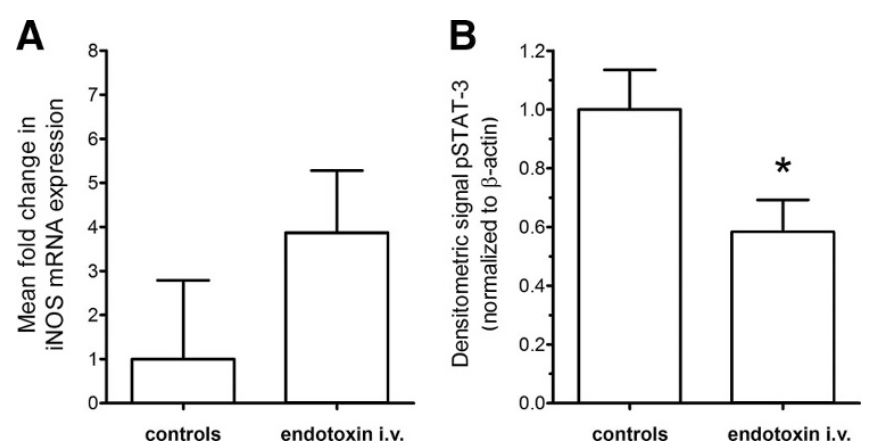

Figure 3. (A) Mean fold change \pm SEM of cardiac iNOS mRNA normalized for ovRPS15 by the $\Delta \Delta C_{\mathrm{t}}$ method. Significant differences in $\Delta C_{\mathrm{t}}(p<0.05)$ compared with control groups are marked by $*$. No significant differences between the systemic endotoxinaemia group $(n=5)$ compared with controls $(n=6)$. ( $B)$ Western blot for pSTAT-3 in fetal myocardium normalized to $\beta$ actin. Depicted are mean and SEM. Significant differences $(p<0.05)$ compared with control groups are marked by $*$. The decrease in phosphorylated STAT-3 content in the systemic endotoxinaemia group $(n=5)$ was significant compared with controls $(n=6)$.

istry for HIF- $1 \alpha$ was consistent with the mRNA data (Fig. $2 B$ ). The number of HIF- $1 \alpha$ positive cells was significantly higher after i.v. endotoxin $(p<0.01$; Fig. $2 B$ and $B 2)$ than in controls (Fig. $2 B$ and $B 1$ ).

Inducible NOS. The changes in mRNA level for iNOS (Fig. 3A) resembled those of HIF-1 $\alpha$ but there were no significant differences between the fetal endotoxinaemia group compared with controls $(p=0.15)$.

Phosphorylated STAT-3. The densitometric signal of pSTAT3 in Western blot (normalized for $\beta$ actin) decreased to $58.3 \%$ in fetal myocardium of the systemic endotoxemia group compared with controls $(p<0.04$, Fig. $3 B)$.

TLR2, TLR4, and IL-6. Fetal endotoxinaemia increased TLR4 mRNA levels in the fetal heart 7.8-fold ( $p=0.03$; Fig. $4 A)$. TLR 2 mRNA increased by 5.6 -fold in the fetal endotoxinaemia group compared with controls $(p=0.04$; Fig. $4 B$ ). IL-6 mRNA was not increased in animals exposed to systemic endotoxinaemia (Fig. 4C).

\section{DISCUSSION}

The clinical observation that fetuses with PROM and preterm parturition have decreased diastolic cardiac function was attributed to asphyctic insults occurring during the birth process (19). However, decreased cardiac function has recently 
A

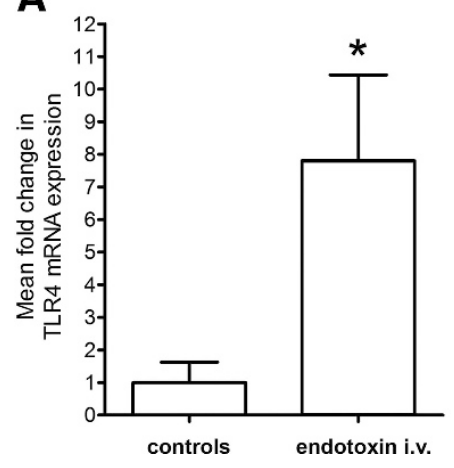

B

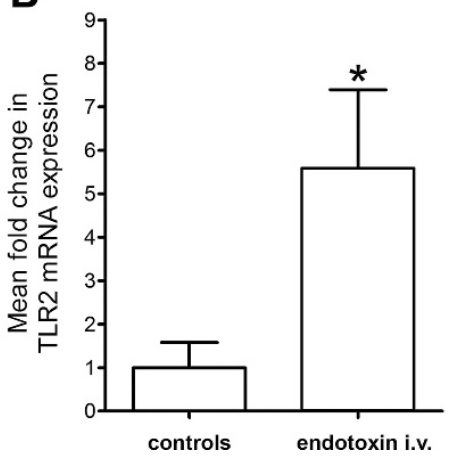

C

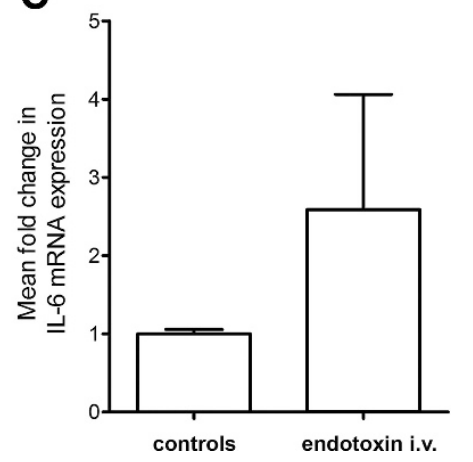

Figure 4. Mean fold change \pm SEM of cardiac TLR4, TLR2, and IL-6 mRNA normalized for ovRPS15 by the $\Delta \Delta C_{\mathrm{t}}$ method. Significant differences in $\Delta C_{\mathrm{t}}(p<$ $0.05)$ compared with control groups are marked by *. (A) Fetal systemic endotoxinaemia increased TLR4 mRNA in the fetal heart $(n=5)$. $(B)$ The increase in TLR2 mRNA content with systemic endotoxinaemia $(n=5)$ was significant compared with controls $(n=6)$. $(C)$ IL-6 did not change. been linked to hypoxia/ischemia because of fetal inflammation $(20,21)$. Preterm labor and delivery in the presence of FIRS and fetal sepsis is often caused by Gram-negative bacteria (11). We hypothesized that endotoxin caused a fetal cardiac inflammatory response by activating TLR 2 and TLR 4 and induced the cytokine cascade via IL-6, which produced NO formation leading to arterial hypotension, tachycardia, and cardiac hypoxia.

To examine this hypothesis, we used a model of preterm sheep that were exposed to i.v. endotoxin in utero. All preterm lambs exposed to endotoxin developed an acute response with reduced oxygenation and increased heart rate after $6 \mathrm{~h}$. After $72 \mathrm{~h}$, the endotoxin exposure led to tachycardia and arterial hypotension, which resulted in a systemic oxygen desaturation. As a consequence, we found that cardiac mRNA and protein levels of HIF- $1 \alpha$, which promotes the expression of genes to protect cardiac oxygen supply by stimulating angiogenesis $(22,23)$, were strongly increased.

Hypotension and reduced cardiac output is thought to be due to an excess of NO, which causes catecholamine-resistant vasodilatation and reduced myocardial inotropy (24). The overproduction of NO by up-regulation of iNOS transcription was shown to contribute to the pathogenesis of septic shock in adults (5). Surprisingly, we only found a trend for upregulation of iNOS, but it did not reach significance. The initial process of $\mathrm{NO}$ generation is thought to occur via constitutive NOS (cNOS) activation rather than by de novo synthesis of iNOS. This is consistent with the short time frame to the onset of myocardial depression (25). Kinugawa et al. (26) demonstrated, using an avian cardiac myocyte model, a biphasic response to IL- 6 administration. IL- 6 given in high concentration produced both early $(<30 \mathrm{~min})$ and late $(24 \mathrm{~h})$ contractile dysfunction of cardiac myocytes, associated with a decrease in intracellular calcium. Early dysfunction could be blocked by pretreatment with a calcium chelator, implicating that the calcium/calmodulin-dependent cNOS is involved. However, late dysfunction could not be blocked by the chelator, supporting the role for the calcium/calmodulin-independent iNOS (26). According to this, we expected to see an increase in iNOS levels $72 \mathrm{~h}$ after exposure to inflammatory stimulus. But although we observed a continuous deterioration in cardiovascular function followed by a starting decompensation after $48 \mathrm{~h}$, we found no significant up-regulation in iNOS levels. In this respect, it seems more likely that the lacking increase in iNOS was because the fetal heart was $72 \mathrm{~h}$ after endotoxin exposure already in a negative feedback loop. This complex negative feedback loop finally leads to deactivation of the Janus kinase (JAK)-STAT-3 (7). Activation and phosphorylation of STAT3 leads to a transcriptional up-regulation of iNOS, whereas inhibition of the STAT3 pathway causes a decrease in iNOS level (27). Consistent with this scenario, we found a significantly decreased phosphorylation of STAT3. But this scenario also implicates that cardiac iNOS is not the main mediator of fetal cardiac dysfunction in endotoxinaemia.

Apart from iNOS, members of the TLR family, TLR4 in particular, are also thought to mediate the endotoxinaemic myocardial dysfunction in adult sepsis patients (28). TLR4 is part of a receptor complex recognizing Gram-negative bacterial endotoxin and is required for endotoxin signal transduction (29). Experiments with TLR4 inhibitors demonstrated a reduced myocardial dysfunction in endotoxinaemia $(28,30,31)$. Here, we detected an increase in fetal cardiac TLR2 and 4 mRNA levels after systemic administration of endotoxin corresponding to the observations in the adult. It has been shown that up-regulation of TLR2 in human white blood cells is a valuable marker for neonatal sepsis, whereas TLR4 levels remained unchanged (32). In the study of Viemann et al., TLR2 levels was as predictive as the classical plasma IL- 6 for the process of neonatal sepsis $(32,33)$. We detected no significant change in cardiac IL-6 mRNA levels in our model. This may be explained by studies in adults showing that plasma IL-6 was produced solely in the periphery in the early stages of heart failure but by the myocardium only in functionally severe endstage disease (34). Therefore, our findings suggest that induction of cardiac IL-6 is a relatively late event in the pathogenesis of fetal endotoxinaemia.

A limitation of our study is that the data sets mainly consist of mRNA measurements. These results may indicate that the examined mediators and receptors change the same way on protein level but this is speculative. The model of preterm sheep has the advantage of being much closer to the human situation with regard to prenatal development compared with rodent models (35). Sheep are well characterized from a physiological and parturition perspective, but their immunology and genome is much less well understood. In addition, there is, relative to mice, a distinct lack of molecular tools available to study experimental tissues (36).

Another limitation of our study is that we used endotoxin instead of a living pathogen. In our model, we could standardize the inflammatory stimulus for all groups, but interactions 
normally taking place between invading pathogen and host could not be studied in our model. A further limitation is that our study design did not allow us to assess the initial acute response of fetal cardiomyocytes to the endotoxin exposure. We chose to study chronic exposure to Gram-negative bacterial endotoxin because there are several clinical implications (14). Endotoxin tolerance increases the risk of infections and mortality and thus is maladaptive in the intensive care setting (37). The maintenance of cardiac function is the crucial therapeutic target during neonatal sepsis and especially septic shock (38), but there is no information whether exposure to FIRS can increase the susceptibility of preterm infant to sepsis-related cardiac failure. In this context, our findings provide indications for possible roles of cardiac TLR2 and TLR4; however, according to our observations, the cardiac iNOS pathway does not seem to play such a crucial role in the development of fetal cardiac dysfunction during Gramnegative endotoxinaemia as it does in the adult.

In summary, systemic endotoxinaemia leads to tachycardia and hypotension in the ovine fetus within $72 \mathrm{~h}$. Activated TLR2 and TLR4 indicated that the injected endotoxin reached the heart, which led to activation of HIF- $\alpha$, suggesting the occurrence of cardiac hypoxia. We did not find any involvement of the cardiac NO pathway in the fetal cardiac dysfunction. The fetal adaptation to inflammation is thus complex and may help to understand clinical adaptation after preterm birth (39).

Acknowledgments. We thank Barbara Ottensmeier and Simone Kolvenbach for the excellent technical help.

\section{REFERENCES}

1. Ren J, Wu S 2006 A burning issue: do sepsis and systemic inflammatory response syndrome (SIRS) directly contribute to cardiac dysfunction? Front Biosci 11:15-22

2. Nemoto S, Vallejo JG, Knuefermann P, Misra A, Defreitas G, Carabello BA, Mann DL 2002 Escherichia coli LPS-induced LV dysfunction: role of toll-like receptor-4 in the adult heart. Am J Physiol Heart Circ Physiol 282:H2316-H2323

3. Yoon BH, Romero R, Park JS, Kim M, Oh SY, Kim CJ, Jun JK 2000 The relationship among inflammatory lesions of the umbilical cord (funisitis), umbilical cord plasma interleukin 6 concentration, amniotic fluid infection, and neonatal sepsis. Am J Obstet Gynecol 183:1124-1129

4. Dougnac A, Riquelme A, Calvo M, Andresen M, Magedzo A, Eugenin E, Marshall G, Gutiérrez M 2001 [Study of cytokines kinetics in severe sepsis and its relationship with mortality and score of organic dysfunction]. Rev Med Chil 129:347-358

5. Yin GQ, Du KH, Gu FR, Fang ZX, Tang JQ, Zhong B, Zhu XY, Wu YW, Lu CP 2007 Early-phase endotoxic shock-induced myocardial injury increases iNOS and selectin expression in macaque primate. Heart Lung Circ 16:85-92

6. Wang M, Zhang W, Crisostomo P, Markel T, Meldrum KK, Fu XY, Meldrum DR 2007 Endothelial STAT3 plays a critical role in generalized myocardial proinflammatory and proapoptotic signaling. Am J Physiol Heart Circ Physiol 293:H2101-H2108

7. Tanimoto K, Saito Y, Hamanaka I, Kuwahara K, Harada M, Takahashi N, Kawakami R, Nakagawa Y, Nakanishi M, Adachi Y, Shirakami G, Fukuda K, Yoshimura A, Nakao K 2005 SOCS1/JAB likely mediates the protective effect of cardiotrophin-1 against lipopolysaccharide-induced left ventricular dysfunction in vivo. Circ J 69:1412-1417

8. Gomez R, Romero R, Ghezzi F, Yoon BH, Mazor M, Berry SM 1998 The fetal inflammatory response syndrome. Am J Obstet Gynecol 179:194-202

9. Romero R, Espinoza J, Goncalves LF, Kusanovic JP, Friel L, Hassan S 2007 The role of inflammation and infection in preterm birth. Semin Reprod Med 25:21-39

10. Romero R, Gomez R, Ghezzi F, Yoon BH, Mazor M, Edwin SS, Berry SM 1998 A fetal systemic inflammatory response is followed by the spontaneous onset of preterm parturition. Am J Obstet Gynecol 179:186-193

11. Stoll BJ, Hansen NI, Higgins RD, Fanaroff AA, Duara S, Goldberg R, Laptook A, Walsh M, Oh W, Hale E 2005 Very low birth weight preterm infants with early onset neonatal sepsis: the predominance of gram-negative infections continues in the National Institute of Child Health and Human Development Neonatal Research Network, 2002-2003. Pediatr Infect Dis J 24:635-639

12. Sandor F, Buc M 2005 Toll-like receptors. I. Structure, function and their ligands. Folia Biol (Praha) 51:148-157
13. Raddatz E, Gardier S, Sarre A 2006 Physiopathology of the embryonic heart (with special emphasis on hypoxia and reoxygenation). Ann Cardiol Angeiol (Paris) 55:79-89

14. Kallapur SG, Jobe AH, Ball MK, Nitsos I, Moss TJ, Hillman NH, Newnham JP, Kramer BW 2007 Pulmonary and systemic endotoxin tolerance in preterm fetal sheep exposed to chorioamnionitis. J Immunol 179:8491-8499

15. Kramer BW, Ladenburger A, Kunzmann S, Speer CP, Been JV, van Iwaarden JF, Zimmermann LJ, Gantert M, Garnier Y 2009 Intravenous lipopolysaccharideinduced pulmonary maturation and structural changes in fetal sheep. Am J Obstet Gynecol 200:195.e1-195.e10

16. Coumans AB, Garnier Y, Supcun S, Jensen A, Berger R, Hasaart TH 2004 The effects of low-dose endotoxin on the umbilicoplacental circulation in preterm sheep. J Soc Gynecol Investig 11:289-293

17. Livak KJ, Schmittgen TD 2001 Analysis of relative gene expression data using real-time quantitative PCR and the 2(-Delta Delta C(T)) Method. Methods 25:402-408

18. Kramer BW, Kramer S, Ikegami M, Jobe AH 2002 Injury, inflammation, and remodeling in fetal sheep lung after intra-amniotic endotoxin. Am J Physiol Lung Cell Mol Physiol 283:L452-L459

19. Ranjit MS 2000 Cardiac abnormalities in birth asphyxia. Indian J Pediatr 67:S26-S29

20. Garnier Y, Coumans AB, Jensen A, Hasaart TH, Berger R 2003 Infection-related perinatal brain injury: the pathogenic role of impaired fetal cardiovascular control. J Soc Gynecol Investig 10:450-459

21. Romero R, Espinoza J, Goncalves LF, Gomez R, Medina L, Silva M, Chaiworapongsa T, Yoon BH, Ghezzi F, Lee W, Treadwell M, Berry SM, Maymon E, Mazor M, DeVore G 2004 Fetal cardiac dysfunction in preterm premature rupture of membranes. J Matern Fetal Neonatal Med 16:146-157

22. Huang LE, Arany Z, Livingston DM, Bunn HF 1996 Activation of hypoxiainducible transcription factor depends primarily upon redox-sensitive stabilization of its alpha subunit. J Biol Chem 271:32253-32259

23. Kallio PJ, Pongratz I, Gradin K, McGuire J, Poellinger L 1997 Activation of hypoxia-inducible factor 1alpha: posttranscriptional regulation and conformational change by recruitment of the Arnt transcription factor. Proc Natl Acad Sci U S A 94:5667-5672

24. Bailey A, Pope TW, Moore SA, Campbell CL 2007 The tragedy of TRIUMPH for nitric oxide synthesis inhibition in cardiogenic shock: where do we go from here? Am J Cardiovasc Drugs 7:337-345

25. Finkel MS, Oddis CV, Jacob TD, Watkins SC, Hattler BG, Simmons RL 1992 Negative inotropic effects of cytokines on the heart mediated by nitric oxide. Science 257:387-389

26. Kinugawa K, Takahashi T, Kohmoto O, Yao A, Aoyagi T, Momomura S, Hirata Y, Serizawa T 1994 Nitric oxide-mediated effects of interleukin-6 on $[\mathrm{Ca} 2+] \mathrm{i}$ and cell contraction in cultured chick ventricular myocytes. Circ Res 75:285-295

27. Bolli R, Dawn B, Xuan YT 2003 Role of the JAK-STAT pathway in protection against myocardial ischemia/reperfusion injury. Trends Cardiovasc Med 13:72-79

28. Baumgarten G, Knuefermann P, Schuhmacher G, Vervolgyi V, von Rappard J, Dreiner U, Fink K, Djoufack C, Hoeft A, Grohe C, Knowlton AA, Meyer R 2006 Toll-like receptor 4, nitric oxide, and myocardial depression in endotoxemia. Shock 25:43-49

29. Poltorak A, He X, Smirnova I, Liu MY, Van Huffel C, Du X, Birdwell D, Alejos E, Silva M, Galanos C, Freudenberg M, Ricciardi-Castagnoli P, Layton B, Beutler B 1998 Defective LPS signaling in C3H/HeJ and C57BL/10ScCr mice: mutations in Tlr4 gene. Science 282:2085-2088

30. Kramer BW, Ikegami M, Moss TJ, Nitsos I, Newnham JP, Jobe AH 2005 Endotoxininduced chorioamnionitis modulates innate immunity of monocytes in preterm sheep. Am J Respir Crit Care Med 171:73-77

31. Niu J, Azfer A, Kolattukudy PE 2008 Protection against lipopolysaccharide-induced myocardial dysfunction in mice by cardiac-specific expression of soluble Fas. J Mol Cell Cardiol 44:160-169

32. Viemann D, Dubbel G, Schleifenbaum S, Harms E, Sorg C, Roth J 2005 Expression of toll-like receptors in neonatal sepsis. Pediatr Res 58:654-659

33. Jean-Baptiste E 2007 Cellular mechanisms in sepsis. J Intensive Care Med 22:63-72

34. Kubota T, Miyagishima M, Alvarez RJ, Kormos R, Rosenblum WD, Demetris AJ, Semigran MJ, Dec GW, Holubkov R, McTiernan CF, Mann DL, Feldman AM, McNamara DM 2000 Expression of proinflammatory cytokines in the failing human heart: comparison of recent-onset and end-stage congestive heart failure. J Heart Lung Transplant 19:819-824

35. Kramer BW, Kallapur S, Newnham J, Jobe AH 2009 Prenatal inflammation and lung development. Semin Fetal Neonatal Med 14:2-7

36. Kemp MW, Saito M, Newnham JP, Nitsos I, Okamura K, Kallapur SG 2010 Preterm birth, infection, and inflammation advances from the study of animal models. Reprod Sci 17:619-628

37. Munoz C, Carlet J, Fitting C, Misset B, Bleriot JP, Cavaillon JM 1991 Dysregulation of in vitro cytokine production by monocytes during sepsis. J Clin Invest 88:1747-1754

38. Brierley J, Carcillo JA, Choong K, Cornell T, Decaen A, Deymann A, Doctor A, Davis A, Duff J, Dugas MA, Duncan A, Evans B, Feldman J, Felmet K, Fisher G, Frankel L, Jeffries H, Greenwald B, Gutierrez J, Hall M, Han YY, Hanson J, Hazelzet J, Hernan L, Kiff J, Kissoon N, Kon A, Irazuzta J, Lin J, Lorts A, Mariscalco M, Mehta R, Nadel S, Nguyen T, Nicholson C, Peters M, OkhuysenCawley R, Poulton T, Relves M, Rodriguez A, Rozenfeld R, Schnitzler E, Shanley T, Kache S, Skippen P, Torres A, von Dessauer B, Weingarten J, Yeh T, Zaritsky A, Stojadinovic B, Zimmerman J, Zuckerberg A 2009 Clinical practice parameters for hemodynamic support of pediatric and neonatal septic shock: 2007 update from the American College of Critical Care Medicine. Crit Care Med 37:666-688

39. Kramer BW, Jobe AH 2005 The clever fetus: responding to inflammation to minimize lung injury. Biol Neonate 88:202-207 